\title{
Herd behaviour in stock markets: an international perspective
}

Islem Boutabba,

Department of Management, IHEC, University of Carthage, Tunisia.

islemboutabba@hotmail.com

\section{ABSTRACT}

In this paper, we study the behavioral finance as a theory that seeks to combine cognitive and psychological components with economic and financial aspects to explain irrationality of financial decisions. It is a paradigm where financial markets are studied using models that are less tight than those based on expected utility theory of Neumann Morgenstern and on arbitrage assumptions. Behavioral finance has two main parts: cognitive psychology and the limits to arbitrage.

Cognitive refers to how people think. There is a large literature in psychology that claims people make asymmetric errors in thinking. Limits to arbitration refer to prediction data where forces of arbitrage circumstances will be effective or not.

Our empirical validation focused on one of the cognitive components: herding. Indeed, we examined herd behaviour in an international context (the United States (DJU), Argentina (MERV), and France (CAC20)) using the model of Chang et al (2000). Our results led us to conclude that there is no herd behaviour.

\section{Indexing terms/Keywords}

Behavioral finance, herd behavior, cognitive biases.

\section{Academic Discipline And Sub-Disciplines}

Finance, behavioral finance;

\section{SUBJECT CLASSIFICATION}

Financial subject classification

\section{TYPE (METHOD/APPROACH)}

Quantitative approach (Econometry).

\section{Council for Innovative Research}

Peer Review Research Publishing System

\section{Journal: JOURNAL OF SOCIAL SCIENCE RESEARCH}

Vol 4, No 2

jssreditor.cir@gmail.com

www.jssronline.com/ojs 


\section{INTRODUCTION}

Researchers have long focused on understanding investment behaviour of market actors and its impact on stock prices. Such behaviour was linked to factors like investment opportunities, tools used to measure performance, behaviour of other market participants, market volatility and presence of speculative trading in financial markets.

Chang et al (2000) examined investment behaviour of market participants in different international markets, in particular the tendency to herd others (herd behaviour). Herding may be interpreted as a rational or irrational form of investment behaviour. According to Devenow and Welch (1996), irrationality relates to the psychology of investors where these latter neglect their prior beliefs and follow blindly other investors. Still, rationality relates to the "principal-agent" problem where managers herd others ignoring completely private information to maintain their reputation in the market (Scharfstein and Stein (1990) and Rajan (1994)). Bikhchandani et al (1992) and Welch (1992) have pointed to this behaviour as an informational descent.

In a recent empirical study, Christie and Huang (1995) examined investment behaviour of market participants in the U.S. stock market. Using cross-sectioned standard deviations of returns (CSSD) as a measure of the average proximity of individual assets returns of the average obtained market, they developed a herd behaviour index. In particular, they examined behaviour of CSSD under different market conditions. They argue that if market participants remove their own predictions about stock prices during periods of significant market movement and they base their investment decisions solely on the aggregate market behaviour, individual stocks returns do not substantially differ from the aggregate market performance, which results in a CSSD smaller than normal.

In this section, we will extend the work of Christie and Huang (1995) in three ways. First, we propose a new and powerful approach to detect herding based on the behaviour of stocks returns. Using a nonlinear regression, we examine the relationship between degree of dispersion of stocks returns (as measured by the absolute cross-sectioned standard deviation of returns), and aggregate market returns. In the presence of a moderate herding, we expect that dispersion of returns will drop (or increase at a decreasing rate) with an increase in market returns. Second, we examine the presence of herding across developed and developing financial markets. Studying herd behaviour is interesting in an international context given the presence of different factors such as the relative importance of institutional investors than individual investors, quality and degree of information disclosure, degree of sophistication of derivatives markets, etc. These may affect investors' behaviour in these markets.

\section{1- METHODOLOGY:}

\section{1-1. Eric C. Chang, Joseph W. Cheng, Ajay Khorana (2000):}

Eric C. Chang, Joseph W. Cheng, Ajay Khorana (2000) have developed an empirical methodology in view of detecting herd behaviour in international equity markets. Specifically, they propose as alternative an approach less robust to that proposed by Christie and Huang (1995). Although the two methods are similar in essence, they often fail to reach the same conclusions. The authors discuss the roots of their methods, its formulation and they compare both of them. Christie and Huang (1995) suggest the use of cross-sectioned standard deviation of returns (CSSD) to detect herd behaviour in the market. CSSD is defined as :

CSSDt $=\sqrt{\frac{\sum_{i=1}^{N}\left(R_{i, t}-R_{m, t}\right)^{2}}{N-1}}$

Where $R_{i, t}$ is the observed stock return in firm $i$ at date $t$ and $R_{m, t}$ is the average cross-sectioned standard deviations of returns $\mathrm{N}$ in the aggregate market portfolio at date $\mathrm{t}$.

This dispersion measure quantifies the average proximity of individual returns to achieved average. Christie and Huang (1995) claim that rational asset pricing models predict that dispersion increases with the absolute market return value as individual equities differ in their sensitivity to market return. However, in case of a herd behaviour (where individuals cancel their own beliefs and base their investment decisions uniquely on market's collective behaviour), asset returns would not deviate far from aggregate market return. Such behaviour will lead to an increase in dispersion and if herding is noticeable it might lead to a decrease in dispersion. Consequently, herd behaviour and rational asset pricing models provide for contrasting predictions of dispersion of market returns.

Christie and Huang (1995) suggest that individuals are more likely to cancel their own beliefs in favour of a market consensus during periods of extreme market movements. Accordingly, Christie and Huang (1995) examine whether asset returns dispersion are significantly lower than average during extreme market movements. They estimate the following estimation:

$\operatorname{CSSDt}=\alpha+\beta^{\mathrm{L}} D_{\mathrm{t}}^{\mathrm{L}}+\beta^{\mathrm{U}} D_{\mathrm{t}}^{\mathrm{U}}+\varepsilon_{\mathrm{t}}$

$\mathrm{D}_{\mathrm{t}}^{\mathrm{L}}=1$, if market return on day $\mathrm{t}$ is at the extreme lower distribution tail, and it is 0 otherwise, and

$\mathrm{D}_{\mathrm{t}}^{\mathrm{U}}=1$, if market return on day $\mathrm{t}$ is at the extreme upper distribution tail, and it is 0 otherwise.

The dummy variables (binary) are there to capture the lower or upper tendency of investment behaviour in relation to the relatively normal markets. Obtaining negative and significant $\beta^{\mathrm{L}}$ and $\beta^{\mathrm{U}}$ coefficients indicates herd behavior. Christie and Huang (1995) use 1 or $5 \%$ of observations at the lower or upper tail of market returns distribution to define extreme price volatility days. 
Using cross-sectioned absolute deviation of returns (CSAD) as a measure of dispersion, Eric C. Chang, Joseph W. Cheng, Ajay Khorana (2000) show that rational asset pricing models predict not only that dispersions of asset returns are an increasing function of market performance but also that the relationship between these two is linear. If market participants tend to follow aggregate market behaviour and ignore their own prior beliefs during periods of strong variations in average prices, then the linear and growing relationship between dispersion and the market return will no longer hold. Rather, the relationship may become non-linearly increasing or even decreasing.

As a starting point of their analysis, Eric C. Chang, Joseph W. Cheng, Ajay Khorana (2000) posit the relationship between CSSAD and market return. Ri indicates return on equities $\mathrm{i}, \mathrm{Rm}$ is return on market portfolio and Et (.) indicates expectation in period t. A conditional version of the CAPM (Black (1972)) can be expressed as-follows:

$\mathrm{E}_{\mathrm{t}}\left(\mathrm{R}_{\mathrm{i}}\right)=\mathrm{v}_{0}+\beta_{\mathrm{i}} \mathrm{E}_{\mathrm{t}}\left(\mathrm{R}_{\mathrm{m}}-\mathrm{v}_{0}\right)$

Where $\mathrm{y}$ denotes the return on zero-beta portfolio, $\beta_{i}$ is a measure of time-unvarying systematic risk of asset $\mathrm{i}=1, \ldots, \mathrm{N}$ and $t=1, \ldots, T$. Moreover, $\beta_{m}$ is systematic risk of the equally weighted market portfolio.

$\beta_{\mathrm{m}}=\frac{1}{\mathrm{~N}} \sum_{\mathrm{i}=1}^{\mathrm{N}} \beta_{\mathrm{i}}$

The absolute value of the deviation of asset $\mathrm{i}(\mathrm{DSA})$ is the expected return in period $t$ from the th period of expected portfolio return and may be expressed as:

$A V D i, t=I \beta_{i}-\beta_{m} \mid E t\left(R_{m}-\gamma_{0}\right)$

Thus, we can define the cross-sectioned absolute deviation of expected stock returns (ECSAD) in period t as follows:

ECSADt $=\frac{1}{N} \sum_{i=1}^{N} A_{V D}, t=\frac{1}{N} \sum_{i=1}^{N}\left|\beta_{i}-\beta_{m}\right| E t\left(R_{m}-v_{0}\right)$

The increasing and linear relationship between dispersion and expected time-varying market returns can be easily shown as follows:

$\frac{\partial \mathrm{ECSAD}_{\mathrm{t}}}{\partial \mathrm{E}_{\mathrm{t}}\left(\mathrm{R}_{\mathrm{m}}\right)}=\frac{1}{\mathrm{~N}} \sum_{\mathrm{i}=1}^{\mathrm{N}}\left|\beta_{\mathrm{i}}-\beta_{\mathrm{m}}\right|>0$
$\frac{\partial^{2} \mathrm{ECSAD}_{\mathrm{t}}}{\partial \mathrm{E}_{\mathrm{t}}\left(\mathrm{R}_{\mathrm{m}}\right)^{2}}=0$

Against the above results, Eric C. Chang, Joseph W. Cheng, Ajay Khorana (2000) propose another herding test that requires additional regression parameter to capture any possible non-linear relationship between dispersion of asset returns and market returns. Indeed, the empirical test of Eric C. Chang, Joseph W. Cheng, Ajay Khorana (2000) is similar to the market timing model proposed by Treynor and Mazuy (1966).

Eric C. Chang, Joseph W. Cheng, Ajay Khorana (2000) use CSADt and Rm,t as a proxy for the unobserved ECSADt and $\mathrm{Et}\left(\mathrm{R}_{\mathrm{m}, \mathrm{t}}\right)$. If market participants are more likely to herd during periods of significant price movements, this latter behaviour may be less than an increase (or decrease) proportional to CSAD. Note that Eric C. Chang, Joseph W. Cheng, Ajay Khorana (2000) use a conditional version of CAPM simply to establish the presence of a linear relationship between ECSADt and $\operatorname{Et}\left(\mathrm{R}_{\mathrm{m}, \mathrm{t}}\right)$. They use ex post data to test presence of herd behaviour in their sample through the average relationship between achieved CSADt and $R_{m, t}$. CSAD is not a herd measure, rather the relationship between CSADt and $\mathrm{R}_{\mathrm{m}, \mathrm{t}}$ is used to detect herd behaviour.

To allow for the possibility that herding degree may be asymmetric, we test the following empirical specification:

$$
\begin{aligned}
& \operatorname{CSAD}_{\mathrm{t}}^{\mathrm{UP}}=\alpha+\gamma_{1}^{\mathrm{UP}}\left|\mathrm{R}_{\mathrm{m}, \mathrm{t}}^{\mathrm{UP}}\right|+\mathrm{Y}_{2}^{\mathrm{UP}}\left(\mathrm{R}_{\mathrm{m}, \mathrm{t}}^{\mathrm{UP}}\right)^{2}+\varepsilon_{\mathrm{t}} \\
& \operatorname{CSAD}_{\mathrm{t}}^{\mathrm{DOWN}}=\alpha+\gamma_{1}^{\text {DOWN }}\left|R_{\mathrm{m}, \mathrm{t}}^{\mathrm{DOWN}}\right|+\gamma_{2}^{\text {DOWN }}\left(R_{\mathrm{m}, \mathrm{t}}^{\text {DOWN }}\right)^{2}+\varepsilon_{\mathrm{t}}
\end{aligned}
$$

Where CSADt is the $A V D_{t}$ means for each asset relative to the equally weighted market portfolio return, $R_{m, t}$ in period $t$, and $I R_{m, t}^{U P} t\left(\mid R_{m, t}^{D O W N} I\right)$ is the absolute value of observed equally weighted return for all available assets on the day $t$ when the market is up (down). Both variables are calculated on a daily basis. Note that to facilitate comparison of the linear term coefficients, absolute values are used in equations (1-8) and (1-9). If, during periods of relatively large price fluctuations, market participants are moving towards herding around indicators such as the average consensus of all market constituents, a nonlinear relationship between CSADt and average market return results. Nonlinearity will be captured by a negative and statistically significant $\mathrm{V}_{2}$ coefficient.

To compare the two methods, in Figure 1, Eric C. Chang, Joseph W. Cheng, Ajay Khorana (2000) trace CSAD measure for each day and use for the equally weighted market return of Hong Kong using assets return over the period between January 1981 and December 1995. The relationship of market return CSAD seems to be linearly positive. By focusing on the right side where achieved average daily returns were all positive, the estimated coefficients and t-statistics for their model is:

$$
\mathrm{CSAD}_{\mathrm{t}}=0.0143+0.3562 \mathrm{R}_{\mathrm{m}, \mathrm{t}}^{\mathrm{UP}}-0.0515\left(\mathrm{R}_{\mathrm{m}, \mathrm{t}}^{\mathrm{UP}}\right)^{2}+\varepsilon_{\mathrm{t}}
$$


The results point to the presence of a positive and statistically significant linear term. However, since the nonlinear term is not significantly negative $\mathrm{CSAD}_{\mathrm{t}}$ has not increased at a decreasing rate nor decreased like the average price movement. Hence rational assets prediction models (as suggested above) have not been violated.

The same conclusion may be true using the methodology suggested by Christie and Huang (1995). Using the 1\% criterion, the estimated coefficients for their model are:

$\operatorname{CSAD}_{\mathrm{t}}=0.0171+0.0254 \mathrm{D}_{\mathrm{t}}^{\mathrm{L}}-0.0239 \mathrm{D}_{\mathrm{t}}^{\mathrm{L}}+\varepsilon_{\mathrm{t}}$

$$
(5.06)^{* *} \quad(5.73)^{* *}
$$

The two estimates of the coefficients of the dummy variable are positive and statistically significant. Thus, the method of Christie and Huang (1995) gives no evidence of a herd behaviour in Hong Kong.

However, both methods may give conflicting results on the presence of herd behaviour. As an illustration, for all positive values $R_{m, t}$, they take a general quadratic relationship between $\operatorname{CSAD}_{t}$ and $R_{m, t}$ of the following form:

$\operatorname{CSAD}_{\mathrm{t}}=\alpha+\mathrm{y}_{1} \mathrm{R}_{\mathrm{m}, \mathrm{t}}+\mathrm{v}_{2} \mathrm{R}_{\mathrm{m}, \mathrm{t}}^{2}$

Where the presence of a negative parameter $\mathrm{V}_{2}$ indicates a herd behaviour in their model. The quadratic relationship suggests that $\operatorname{CSAD}_{t}$ reaches its maximum value when $R_{m, t}^{*}=-\left(V_{1} / \gamma_{2}\right)$. Differently put, as $R_{m, t}$ increases, where the achieved average daily returns are less (greater) than $\mathrm{R}_{\mathrm{m}, \mathrm{t}}^{*} \mathrm{CSAD}_{\mathrm{t}}$ is an upward trend (downward). At least some, if not all, of the $R_{m, t}$ values during periods of market stress fall in a region where $\operatorname{CSAD}_{t}$ is a downward trend, in the model of Christie and Huang (1995) $\beta^{\mathrm{U}}$ will never be negative. For example, using $3 \%$ of average market return as a threshold of market stress, with $\gamma_{1}=0.3562$, the estimated value of the $\gamma_{2}$ parameter needs to be -5.937 or smaller before it is possible that the $\beta^{\mathrm{U}}$ parameter is negative. Thus, Christie and Huang's (1995) approach needs a much larger magnitude of nonlinearity in return dispersion suggesting a relationship of a herding evidence suggested by rational asset pricing models.

\section{2 - PRESENTATION OF DATA AND RESEARCH HYPOTHESES:}

\section{2-1 Presentation of data:}

To conduct our empirical study, we use the time series of three market indices and their components. The first index is the U.S. "Dow Jones Utility Average" (DJU) index which consists of 15 firms. The second is the French (CAC20) index which consists of 20 firms. The third index is the Merval Buenos Aires (MERV) Argentina index which consists of 18 firms.

The time series of the DJU index and its components start on 21/21/1999 and end on 04/04/2012. Those of the CAC20 index and its components start on 14/02/2005 and end on 04/04/2012. While those of the MERV index and its components start on 04/01/2005 and end on 04/04/2012. Note that data frequency is daily and data are extracted from the Yahoo Finance site!

\section{2-2 The research hypotheses:}

We aim at validating the following two hypotheses:

- Hypothesis 1: There is herd behaviour among investors in financial markets,

- Hypothesis 2: Each investor behaves according to their own conceptions and beliefs about the financial market.

\section{3 - EMPIRICAL RESULTS AND THEIR INTERPRETATION:}

\section{3-1 Time series Descriptive statistics:}

A. $\quad$ Descriptive statistics of DJU index and its components:

The table below summarizes the statistical characteristics of the time series DJU index and its components:

Table 1. Descriptive statistics DJU index and its components

\begin{tabular}{|c|c|c|c|c|c|c|c|c|c|}
\hline $\begin{array}{c}\text { Statistic } \\
\mathbf{s}\end{array}$ & DJU & DJU² & CSAD & DJUup & DJU²up & CSADup & $\begin{array}{c}\text { DJUdow } \\
n\end{array}$ & 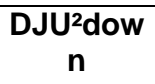 & $\begin{array}{c}\text { CSADdow } \\
n\end{array}$ \\
\hline Mean & $\begin{array}{l}0.000258 \\
4\end{array}$ & $\begin{array}{l}0.000186 \\
4\end{array}$ & $\begin{array}{l}0.015986 \\
8\end{array}$ & $\begin{array}{l}0.008574 \\
9\end{array}$ & $\begin{array}{l}0.000167 \\
7\end{array}$ & $\begin{array}{l}0.015235 \\
3\end{array}$ & $\begin{array}{l}- \\
0.010012 \\
6\end{array}$ & $\begin{array}{l}0.000209 \\
5\end{array}$ & 0.016915 \\
\hline $\begin{array}{l}\text { Maximu } \\
\mathrm{m}\end{array}$ & $\begin{array}{l}0.141756 \\
8\end{array}$ & 0.020095 & $\begin{array}{l}0.169825 \\
3\end{array}$ & $\begin{array}{l}0.141756 \\
8\end{array}$ & 0.020095 & $\begin{array}{l}0.120145 \\
3\end{array}$ & $\begin{array}{l}- \\
0.000025 \\
9\end{array}$ & $\begin{array}{l}0.009239 \\
4\end{array}$ & 0.1698253 \\
\hline
\end{tabular}


ISSN 2321-1091

\begin{tabular}{|c|c|c|c|c|c|c|c|c|c|}
\hline Minimum & $\begin{array}{l}0.096121 \\
7\end{array}$ & 0 & $\begin{array}{l}0.001378 \\
7\end{array}$ & 0 & 0 & $\begin{array}{l}0.002137 \\
6\end{array}$ & $\begin{array}{l}0.096121 \\
7\end{array}$ & $\begin{array}{l}6.68 \times 10- \\
10\end{array}$ & 0.0013787 \\
\hline $\begin{array}{l}\text { Skewnes } \\
\mathrm{s}\end{array}$ & $\begin{array}{l}0.240547 \\
7\end{array}$ & 15.12423 & 3.452512 & 4.542882 & 17.18655 & 2.93785 & $-\overline{2.555798}$ & 8.076176 & 3.730976 \\
\hline Kurtosis & 13.5476 & 346.152 & 24.09903 & 42.43151 & 388.302 & 16.95763 & 13.55485 & 96.69288 & 26.95633 \\
\hline Median & $\begin{array}{l}0.000640 \\
6\end{array}$ & $\begin{array}{l}0.000042 \\
3\end{array}$ & $\begin{array}{l}0.012247 \\
9\end{array}$ & $\begin{array}{l}0.006299 \\
7\end{array}$ & $\begin{array}{l}0.000039 \\
7\end{array}$ & $\begin{array}{l}0.011740 \\
4\end{array}$ & $\begin{array}{l}0.006842 \\
4\end{array}$ & $\begin{array}{l}0.000046 \\
8\end{array}$ & 0.0127718 \\
\hline $\begin{array}{l}\text { Stand. } \\
\text { dev }\end{array}$ & $\begin{array}{l}0.013652 \\
9\end{array}$ & $\begin{array}{l}0.000660 \\
7\end{array}$ & $\begin{array}{l}0.013521 \\
7\end{array}$ & $\begin{array}{l}0.009706 \\
3\end{array}$ & $\begin{array}{l}0.000733 \\
3\end{array}$ & $\begin{array}{l}0.012361 \\
7\end{array}$ & $\begin{array}{l}0.010457 \\
2\end{array}$ & $\begin{array}{l}0.000557 \\
6\end{array}$ & 0.0147816 \\
\hline
\end{tabular}

The descriptive statistics of the DJU lead us to conclude that index return shows a high variability as the standard deviation is relatively high (0.0136529). Indeed, this index return varies between a minimum of -0.0961217 and maximum of 0.1417568 with an average of 0.0002584 . However, the CSAD variable shows a standard deviation of 0.0135217 , which is relatively high as the average of this variable is 0.0159868 . It varies between a minimum value of 0.0013787 and a maximum value of 0.1698253 .

Regarding the DJUup variable, it shows an average of 0.0085749 , a maximum value of 0.1417568 and a minimum value of 0.0013787 . Its standard deviation is 0.0097063 . The DJUdown variable exhibits an average of -0.0100126 , a maximum value of -0.0000259 and a minimum value of -0.0961217 . Its standard deviation is 0.0104572 .

Concerning the nature of distributions, Skewness values are all positive except for the DJUdown variable, and then, distributions gear to the left of the median and the right tails are flatter. However, kurtosis is always greater than 3 , and therefore, all distributions are leptokurtic.

\section{B. $\quad$ Descriptive statistics of the MERV index and its components:}

The table below shows the descriptive statistics of the MERV index's time series and its components:

Table 2. Descriptive statistics of the MERV index and its components

\begin{tabular}{|c|c|c|c|c|c|c|c|c|c|}
\hline $\begin{array}{c}\text { Statistic } \\
\mathbf{S}\end{array}$ & MERV & MERV $^{2}$ & CSAD & $\begin{array}{c}\text { MERVu } \\
\mathbf{p}\end{array}$ & $\begin{array}{c}\text { MERV }^{2} u \\
\mathbf{p}\end{array}$ & CSADup & $\begin{array}{l}\text { MERVdo } \\
\text { wn }\end{array}$ & $\begin{array}{c}\text { MERV }^{2} \text { do } \\
\text { wn }\end{array}$ & $\begin{array}{l}\text { CSADdo } \\
\text { wn }\end{array}$ \\
\hline Mean & $\begin{array}{l}0.00053 \\
25\end{array}$ & $\begin{array}{l}0.000366 \\
2\end{array}$ & $\begin{array}{l}0.02366 \\
2\end{array}$ & $\begin{array}{l}0.01285 \\
94\end{array}$ & $\begin{array}{l}0.00032 \\
19\end{array}$ & $\begin{array}{l}0.02329 \\
38\end{array}$ & $\overline{-} 0.0138986$ & 0.000418 & $\begin{array}{l}0.024093 \\
1\end{array}$ \\
\hline $\begin{array}{l}\text { Maximu } \\
\mathrm{m}\end{array}$ & $\begin{array}{l}0.10995 \\
16\end{array}$ & $\begin{array}{l}0.014757 \\
3\end{array}$ & $\begin{array}{l}0.14135 \\
57\end{array}$ & $\begin{array}{l}0.10995 \\
16\end{array}$ & $\begin{array}{l}0.01208 \\
93\end{array}$ & $\begin{array}{l}0.13416 \\
54\end{array}$ & $-\overline{0} 0000158$ & 0.0147573 & $\begin{array}{l}0.141355 \\
7\end{array}$ \\
\hline $\begin{array}{l}\text { Minimu } \\
\mathrm{m}\end{array}$ & $\begin{array}{l}- \\
0.12147 \\
97\end{array}$ & & $\begin{array}{l}0.00638 \\
51\end{array}$ & 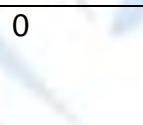 & 0 & $\begin{array}{l}0.00679 \\
99\end{array}$ & $\begin{array}{l}- \\
0.1214797\end{array}$ & $2.5 \times 10^{-10}$ & $\begin{array}{l}0.006385 \\
1\end{array}$ \\
\hline $\begin{array}{l}\text { Skewne } \\
\text { ss }\end{array}$ & $\begin{array}{l}0.43414 \\
27\end{array}$ & 7.667422 & $\begin{array}{l}2.64577 \\
7\end{array}$ & 2.47243 & $\begin{array}{l}7.65673 \\
1\end{array}$ & $\begin{array}{l}2.66175 \\
1\end{array}$ & -2.520644 & 7.226853 & 2.617562 \\
\hline Kurtosis & $\begin{array}{l}7.93430 \\
2\end{array}$ & 84.20572 & 13.9216 & $\begin{array}{l}12.8874 \\
7\end{array}$ & $\begin{array}{l}87.9561 \\
8\end{array}$ & $\begin{array}{l}14.2351 \\
7\end{array}$ & 12.80708 & 72.15165 & 13.50924 \\
\hline Median & $\begin{array}{l}0.00107 \\
58\end{array}$ & $\begin{array}{l}0.000009 \\
07\end{array}$ & $\begin{array}{l}0.01943 \\
04\end{array}$ & $\begin{array}{l}0.00986 \\
75\end{array}$ & $\begin{array}{l}0.00009 \\
74\end{array}$ & $\begin{array}{l}0.01929 \\
51\end{array}$ & $\overline{-}-0092883$ & 0.0000863 & $\begin{array}{l}0.019922 \\
2\end{array}$ \\
\hline $\begin{array}{l}\text { Stand. } \\
\text { dev }\end{array}$ & $\begin{array}{l}0.01913 \\
45\end{array}$ & $\begin{array}{l}0.000960 \\
7\end{array}$ & $\begin{array}{l}0.01462 \\
62\end{array}$ & $\begin{array}{l}0.01251 \\
96\end{array}$ & $\begin{array}{l}0.00080 \\
3\end{array}$ & $\begin{array}{l}0.01417 \\
87\end{array}$ & 0.0150044 & 0.0011157 & $\begin{array}{l}0.015130 \\
6\end{array}$ \\
\hline
\end{tabular}

Regarding the MERV index, the descriptive statistics shows that the index return has a high variability as the standard deviation is relatively high 0.0191345 . Index return varies indeed between a minimum value of 0.1214797 and a maximum value of 0.1099516 and an average of 0.0005325 . The CSAD variable has a standard deviation of 0.0146262 which is relatively high as the average of this variable is 0.023662 . Indeed index return varies between a minimum value of 0.0063851 and a maximum value of 0.1413557 . 
The descriptive statistics of the MERVup variable exhibits an average of 0.0128594 , and varies between a maximum value of 0.1099516 and a minimum value of zero with a standard deviation of 0.0125196 , while the MERVdown variable exhibits an average of -0.0138986 , a minimum value of -0.1214797 , a maximum value of -0.0000158 and a standard deviation of 0.0150044 .

Regarding the shape of the distributions, Skewness values are all positive except for the MERV and MERV down variables, then the distributions gear to the left of the median and the right tails are flatter. However, kurtosis coefficient is always superior to 3 , and consequently all distributions are leptokurtic.

Regarding the MERV index, the descriptive statistics shows that the index return has a high variability as the standard deviation is relatively high 0.0191345 . Index return varies indeed between a minimum value of 0.1214797 and a maximum value of 0.1099516 and an average of 0.0005325 . The CSAD variable has a standard deviation of 0.0146262 which is relatively high as the average of this variable is 0.023662 . Indeed index return varies between a minimum value of 0.0063851 and a maximum value of 0.1413557 .

The descriptive statistics of the MERVup variable exhibits an average of 0.0128594 , and varies between a maximum value of 0.1099516 and a minimum value of zero with a standard deviation of 0.0125196 , while the MERVdown variable exhibits an average of -0.0138986 , a minimum value of -0.1214797 , a maximum value of -0.0000158 and a standard deviation of 0.0150044 .

Regarding the shape of the distributions, Skewness values are all positive except for the MERV and MERV down variables, then the distributions gear to the left of the median and the right tails are flatter. However, kurtosis coefficient is always superior to 3 , and consequently all distributions are leptokurtic.

\section{Descriptive statistics of the CAC20 index and its components:}

The table below shows the descriptive statistics of the CAC20 index's time series and its components:

\begin{tabular}{|c|c|c|c|c|c|c|c|c|c|}
\hline $\begin{array}{c}\text { Statistic } \\
\mathbf{s}\end{array}$ & CAC & CAC $^{2}$ & CSAD & CACup & CAC $^{2}$ up & CSADup & $\underset{n}{\text { CACdow }}$ & $\begin{array}{c}\text { CAC }^{2} \text { dow } \\
n\end{array}$ & $\begin{array}{c}\text { CSADdow } \\
n\end{array}$ \\
\hline Mean & $\begin{array}{l}0.000334 \\
8\end{array}$ & 0.000217 & $\begin{array}{l}0.017705 \\
4\end{array}$ & $\begin{array}{l}0.009673 \\
1\end{array}$ & $\begin{array}{l}0.000201 \\
6\end{array}$ & $\begin{array}{l}0.017129 \\
3\end{array}$ & $\begin{array}{l}- \\
0.010625 \\
5\end{array}$ & $\begin{array}{l}0.000235 \\
1\end{array}$ & 0.0183816 \\
\hline $\begin{array}{l}\text { Maximu } \\
\mathrm{m}\end{array}$ & $\begin{array}{l}0.097104 \\
4\end{array}$ & $\begin{array}{l}0.009429 \\
3\end{array}$ & $\begin{array}{l}0.461086 \\
5\end{array}$ & $\begin{array}{l}0.097104 \\
4\end{array}$ & $\begin{array}{l}0.009429 \\
3\end{array}$ & $\begin{array}{l}0.461086 \\
5\end{array}$ & $\begin{array}{l}-5.48 x \\
10-6\end{array}$ & $\begin{array}{l}0.008294 \\
2\end{array}$ & 431 \\
\hline Mini & $\begin{array}{l}- \\
0.091072 \\
7\end{array}$ & 0 & $\begin{array}{l}0.003244 \\
1\end{array}$ & 0 & 0 & $\begin{array}{l}0.003244 \\
1\end{array}$ & $\begin{array}{l}- \\
0.091072 \\
7\end{array}$ & $3 \times 10-11$ & 442 \\
\hline $\begin{array}{l}\text { Skewnes } \\
\text { s }\end{array}$ & $\begin{array}{l}0.059196 \\
7\end{array}$ & 8.143216 & 15.16021 & 3.141813 & 8.938308 & 16.78666 & -2.14701 & 6.840279 & 1.983447 \\
\hline Kurtosis & 8.496713 & 94.31637 & 414.8735 & 18.88821 & 104.8994 & 398.741 & 10.08097 & 74.04674 & 8.67728 \\
\hline Median & $\begin{array}{l}0.000865 \\
5\end{array}$ & $\begin{array}{l}0.000047 \\
4\end{array}$ & $\begin{array}{l}0.014305 \\
3\end{array}$ & $\begin{array}{l}0.006853 \\
2\end{array}$ & 0.000047 & 3843 & $\begin{array}{l}- \\
0.006959 \\
9\end{array}$ & $\begin{array}{l}0.000048 \\
4\end{array}$ & 0.0149622 \\
\hline $\begin{array}{l}\text { Stand. } \\
\text { dev }\end{array}$ & $\begin{array}{l}0.014732 \\
6\end{array}$ & $\begin{array}{l}0.000594 \\
4\end{array}$ & $\begin{array}{l}0.015442 \\
3\end{array}$ & $\begin{array}{l}0.010399 \\
7\end{array}$ & $\begin{array}{l}0.000621 \\
4\end{array}$ & $\begin{array}{l}0.018209 \\
5\end{array}$ & $\begin{array}{l}0.011063 \\
4\end{array}$ & $\begin{array}{l}0.000560 \\
9\end{array}$ & 0.0113407 \\
\hline
\end{tabular}

Table 3. Descriptive statistics of the CAC20 index and its components

The descriptive statistics of the CAC index shows a high degree of variability as the standard deviation is relatively high 0.0147326 . The return of this index varies between a minimum value of -0.0910727 and a maximum value of 0.0971044 , with an average of 0.0003348 . The CSAD has a standard deviation of 0.0154423 which is relatively high as the mean of this variable is 0.0177054 . The return of this index varies between a minimum value of 0.0032441 and a maximum value of 0.4610865 .

Regarding the CACup variable, it shows a mean of 0.0096731 , which varies between a minimum value of zero and a maximum value of 0.0971044 , with a standard deviation of 0.0103997 , while the CACdown variable shows a mean of 0.0106255 , a minimum value of -0.0910727 and a maximum value of $-5.48 \times 10-6$, and a standard deviation as high as 0.0110634 .

Regarding the shape of the distributions, Skewness values are all positive except for the CACdown variable, then the distributions gear to the left of the median and the right tails are flatter. However, kurtosis coefficient is always superior to 3 and consequently all distributions are leptokurtic. 


\section{3-2 The results ad their interpretation:}

A. Results of the regression of the diatomic variables

Results of the regression of the diatomic variables are reported in the following table:

Table 4. Results of the regression of the diatomic variables

\begin{tabular}{|c|c|c|c|c|c|c|c|c|c|}
\hline \multirow{2}{*}{$\begin{array}{c}\text { Pays } \\
\text { (Période } \\
\text { d'étude) }\end{array}$} & \multicolumn{3}{|c|}{ Critère de 1\% } & \multicolumn{3}{c|}{ Critère de 2\% } & \multicolumn{3}{c|}{ Critère de 5\% } \\
\cline { 2 - 9 } & $\boldsymbol{\alpha}$ & $\boldsymbol{\beta}^{\mathbf{L}}$ & $\boldsymbol{\beta}^{\mathbf{U}}$ & $\boldsymbol{\alpha}$ & $\boldsymbol{\beta}^{\mathbf{L}}$ & $\boldsymbol{\beta}^{\mathbf{U}}$ & $\boldsymbol{\alpha}$ & $\boldsymbol{\beta}^{\mathbf{L}}$ & $\boldsymbol{\beta}^{\mathbf{U}}$ \\
\hline DJU & 0.0131551 & 0.017446 & 0.0368255 & 0.0132159 & - & 0.0384075 & 0.0132159 & - & 0.0384075 \\
\hline $\begin{array}{c}(21 / 12 / 1999- \\
04 / 04 / 2012)\end{array}$ & $(78.11)^{\star *}$ & $(10.42)^{\star *}$ & $(57.11)^{\star *}$ & $(77.18)^{\star *}$ & - & $(60.25)^{\star *}$ & $(77.18)^{\star *}$ & - & $(60.25)^{\star *}$ \\
\hline CAC20 & 0.0159302 & 0.0009696 & 0.0448645 & 0.0159333 & - & 0.0450405 & 0.0159333 & - & 0.0450405 \\
\hline $\begin{array}{c}(14 / 02 / 2005- \\
02 / 04 / 2012)\end{array}$ & $(49.84)^{\star *}$ & $(0.29)$ & $(26.10)^{\star *}$ & $(49.89)^{\star *}$ & - & $(27.98)^{\star *}$ & $(49.89)^{\star *}$ & - & $(27.98)^{\star *}$ \\
\hline MERV & 0.02133 & 0.0035556 & 0.0496054 & 0.02133 & - & 0.0503765 & 0.02133 & - & 0.0503765 \\
\hline $\begin{array}{c}(04 / 01 / 2005- \\
04 / 04 / 2012)\end{array}$ & $(87.40)^{* *}$ & $(1.32)$ & $(38.90)^{\star *}$ & $(87.39)$ & - & $(44.40)^{\star *}$ & $(87.39)^{\star *}$ & - & $(44.40)^{\star *}$ \\
\hline
\end{tabular}

We start our study of the presence of herd behaviour in the three financial markets using regression tests of the diatomic variables that are similar to $\mathrm{CH}$. The first change relates to replacing CSSD by CSAD as a measure of dispersion. The coefficients of the diatomic variables capture the differences between CSAD and highlight the presence of herd behaviour over trading days with upward and downward extreme price movements. Equation 2 is estimated using $1 \%, 2 \%$ and $5 \%$ of price movement days as a definition of extreme price movements (Chang et al. (2000)). In the table below, we report the estimation of the parameters in terms of t-statistics consistent with heteroscedasticity.

In the first model (the $1 \%$ criterion), we noticed positive and statistically significant $\beta^{\mathrm{L}}$ and $\beta^{\mathrm{U}}$ (exception is $\beta^{\mathrm{L}}$ of CAC20 and MERV). Consequently, stocks returns dispersion tends to increase rather decrease during periods of price extreme movements. The two other models show positive and significant $\beta^{\mathrm{U}}$ yet non-significant and null $\beta^{\mathrm{L}}$. Consequently, stocks returns dispersion tends to increase rather decrease during periods of price upward extreme movements.

This is inconsistent with the operational definition of $\mathrm{CH}$ which stipulates a decrease in dispersion levels. Given the similarity between degree of economic development for these countries and degree of their financial markets' integration, these results are not surprising. As a proof of market capitals integration, Campbell and Hamao (1992) found a comovement in expected excess returns across different developed countries.

A. The results of the regression of the general model

The table below reports the results of the regressions of absolute standard deviation in daily frequencies on the squared term of market portfolio returns:

Table 5. The results of the regression of the general model

\begin{tabular}{|c|c|c|c|c|c|}
\hline \multirow{2}{*}{$\begin{array}{c}\text { Pays } \\
\text { (Période d'étude) }\end{array}$} & \multicolumn{4}{|c|}{ Modèle Total } & \multirow[b]{2}{*}{$\mathbf{F}$} \\
\hline & $\alpha$ & $\gamma_{1}$ & $\gamma_{2}$ & $\overline{\mathbf{R}^{2}}$ & \\
\hline DJU & 0.0139217 & -0.1167619 & 11.24022 & 0.3049 & $678.74^{* *}$ \\
\hline $\begin{array}{l}(21 / 12 / 1999- \\
04 / 04 / 2012)\end{array}$ & $(66.08)^{\star \star}$ & $(-7.84)^{\star \star}$ & $(36.51)^{\star \star}$ & & \\
\hline CAC20 & 0.0153175 & -0.047649 & 11.0765 & 0.1814 & $183.89^{* *}$ \\
\hline $\begin{array}{l}(14 / 02 / 2005- \\
02 / 04 / 2012)\end{array}$ & $(41.85)^{\star *}$ & $(-2.04)^{*}$ & $(19.13)^{\star *}$ & & \\
\hline MERV & 0.0197699 & 0.0577134 & 10.54434 & 0.4697 & $794.66^{* *}$ \\
\hline $\begin{array}{l}04 / 01 / 2005- \\
04 / 04 / 2012)\end{array}$ & $(73.23)^{\star *}$ & $(4.34)^{\star *}$ & $(39.84)^{\star *}$ & & \\
\hline
\end{tabular}


According to Chang et al. (2000), a significantly negative coefficient $\gamma_{2}$ is evidence of the presence of herd behavior in financial markets, while an insignificant coefficient $\gamma_{2}$ indicates lack of herding. It should be noted that the significance of this coefficient indicates non-linearity between the CSAD and market return.

This table shows a significance of $\mathrm{V}_{2}$ at the $1 \%$ threshold for the three markets over the different study periods. Nevertheless, the coefficients are all positive. Accordingly, we may conclude that non-linearity between CSAD and squared return is confirmed. Fisher's test for the three markets is significant at the $1 \%$ level and consequently the model is significant. However, adjusted $\mathrm{R}^{2}$ has an average value for DJU and MERV and low for CAC20.

According to Mc Queen et al. (1996) a significantly positive $\gamma_{2}$ coeffcicient indicates extra-dispersion due to the stocks' slow response to good news.

\section{A. Non-linearity between CSAD and market return}

The table below reports the results of the regressions of absolute standard deviation in daily frequencies on the squared term of market portfolio returns under the two scenarios: upward market and downward market.

Table 6. The results of the regressions of upward and downward markets models

\begin{tabular}{|c|c|c|c|c|c|c|c|}
\hline \multirow{2}{*}{$\begin{array}{c}\text { Countries } \\
\text { (study period) }\end{array}$} & \multicolumn{4}{|c|}{ Model A } & \multicolumn{3}{|c|}{ Model B } \\
\hline & $\alpha$ & $\gamma_{1}^{\mathrm{UP}}$ & $\gamma_{2}^{\mathrm{UP}}$ & $\overline{\mathbf{R}^{2}}$ & $\alpha$ & $\gamma_{1}^{\text {DOWN }}$ & $\gamma_{2}^{\text {DOWN }}$ \\
\hline DJU & 0.0093876 & 0.6512496 & 1.570007 & 0.3466 & 0.0090097 & -0.6840649 & 5.039995 \\
\hline $\begin{array}{l}(21 / 12 / 1999- \\
04 / 04 / 2012)\end{array}$ & $(24.69)^{\star *}$ & $(15.31)^{\star \star}$ & $(2.79)^{\star *}$ & & $(17.81)^{\star *}$ & $(-11.47)^{\star *}$ & $(4.51)^{\star \star}$ \\
\hline CAC20 & 0.013704 & 0.3973279 & 4.541271 & 0.1348 & 0.0117894 & -0.5794102 & 1.852739 \\
\hline $\begin{array}{l}(14 / 02 / 2005- \\
02 / 04 / 2012)\end{array}$ & $(12.95)^{\star \star}$ & $(3.59)^{\star \star}$ & $(2.45)^{\star}$ & & $(22.43)^{\star \star}$ & $(-9.41)^{\star \star}$ & (1.53) \\
\hline MERV & 0.01418 & 0.5849279 & 4.944838 & 0.5999 & 0.0146642 & -0.643428 & 1.163105 \\
\hline $\begin{array}{l}(04 / 01 / 2005- \\
04 / 04 / 2012)\end{array}$ & $(27.38)^{\star \star}$ & $(11.90)^{\star *}$ & $(6.45)^{\star *}$ & & $(24.02)^{\star \star}$ & $(-12.33)^{* *}$ & (1.66) \\
\hline
\end{tabular}

This table reports results of the relationship between CSAD and market return during upward and downward price movements. In model A, we examined the relationship between CSAD and market return during upward market price movements. We found positive and significant $\gamma_{2}^{\mathrm{UP}}$ coefficients. Significance for MERV and DJU is at the $1 \%$ level while that for CAC20 is at the $5 \%$ level. Model $A$ is globally significant (significant $F_{A}$ at the $1 \%$ level for the three markets). $R^{2}$ is average for DJU and MERV and low for CAC20. Consequently, these results indicate that there is an additional dispersion due to stocks' slow response to good news.

In model $\mathrm{B}$, we studied the relationship between CSAD and market return during downward market price movements. We found insignificant $Y_{2}^{\text {DOWN }}$ coefficients for CAC 20 and MERV and significantly positive for DJU (at the 1\% level). However, global significance of model $B$ is validated at the $1 \%$ level and $\overline{\mathrm{R}^{2}}$ is average for the three markets. Consequently, we may conclude that there is no herd behaviour on CAC20 and MERV during downward market price movements, whereas the result for the DJU indicates the presence of an additional dispersion due to stocks' slow response to good news.

In this section, we tried to examine investment behaviour of markets participants in three different international markets (DJU, CAC20 and MERV), in particular their tendency to imitate aggregate market behaviour.

To that end, we used a variety of empirical tests taken after Christie and Huang (1995). The main aim of our approach is to show that stocks return dispersion is measured by cross-sectioned standard deviation of returns (CSAD) and that rational asset pricing models can predict not only that dispersion is an increasing function of market return but also that the relationship is linear. In addition, a growing tendency of market participants to herd around market consensus during periods of large price movements is sufficient to convert the linear relationship into a nonlinear relationship.

To capture this effect, we used a non-linear regression that is similar to market timing measurement of Mazuy and Treynor (1966).

Our empirical tests indicate that during periods of extreme price movements, dispersion of equity returns of the DJU, CAC20 and MERV markets tends to increase rather than decrease. Then, we were able to conclude on the absence of herd behaviour. These results are consistent with those of Christie and Huang (1995) and Jurkatis, Kremer and Nautz 
(2012). This finding can be explained by full dissemination of information on these markets (Chang et al. (2000) and Preis, Moat and Stanley (2013)).

Following conventional financial theory, rational investors are those who seek to maximize their wealth. However, there are several cases where psychology and emotions influence our decisions. Therefore, our behaviour will be unpredictable and irrational.

\section{ACKNOWLEDGMENTS}

Our thanks to all the people who have contributed towards development of this work.

\section{REFERENCES}

[1] Chang, E., Cheng, J. and A. Khorana. (2000). An examination of herd behavior in asset markets: an international perspective. Journal of Banking and Finance, 24(10), 1651-1679.

[2] Christie, W. and R. D. Huang. (1995). Following pied piper: do individual returns herd around the market?. Financial Analysts Journal, 51(4), 31-37.

[3] Devenow (A.) and Welch (I.) (1996) : «Rational Herding in Financial Economics », European Economic Review, 40, 603-615.

[4] Jurkatis, S., Kremer, S. et Nautz, D., 2012,"Correlated Trades and Herd Behavior in the Stock Market”, SFB 649 Discussion Papier 2012-035.

[5] Preis, T.,Moat, H. S. et Stanley, H.E., 2013,"Quantifying Trading Behavior in Financial Markets Using Google Trends", Scientific Reports3,Article number:1684.

[6] Scharfstein (D.) and Stein (J.) (1990) : « Herd Behavior and Investment », American Economic Review, 80, 465-479.

\section{Author' biography with Photo}

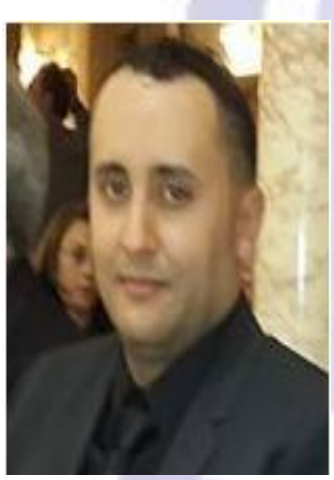

Name \& surname:

\section{Islem BOUTABBA}

Address $\quad: 3$ rue des Ecoles La Goulette, Tunisia

Telephone : :21698203744

E-mail :islemboutabba@hotmail.com

Date of birth : :5 March 1980

Nationality :Tunisian

Sex : Male

Marital status : Single

\section{Education/Qualifications}

2007-2008 University of Carthage, IHEC, Masters in Finance, currency and banks.

2004-2005 University of Sousse, ISG, Mastery in finance.

\section{Employment to Date/Work Experience}

2008-present University teacher in ESC, University of Manouba.

2007-2008 Backoffice treasurer in ABC bank. 